\title{
TOURISM AS A POSSIBLE MEANS OF DEVELOPMENT OF THE DISADVANTAGED SETTLEMENTS, ON THE EXAMPLE OF ÓPUSZTASZER VILLAGE HELGA KOVÁCS* - LEVENTE KOMAREK
}

\author{
University of Szeged, Institute of Economics and Rural Development, Hungary \\ * Corresponding author: kovacs.helga@mgk.u-szeged.hu
}

\begin{abstract}
The alternative source of income for those people who are living in rural settlements is the creation of services and basic infrastructure for rural tourism. The tourism contributes to the creation of new jobs, therefore increases the rural employment and also supports the local cultural and natural heritage. The reduction of unemployment and the expansion of services and incomes for the local people can help raise the living standards and maintain the rural way of life. In our study, we examined the touristic offers of Ópusztaszer and the role of local tourism service providers. We searched for the man-made and natural values of the settlement and in connection with this, we made a SWOT analysis to assess the local tourism potential. Many forms of rural tourism have developed in Ópusztaszer, including equestrian tourism, rural tourism, cultural tourism and ecotourism. The town has many untapped tourist opportunities; rethinking and exploiting them could contribute to sustainable tourism in the settlement in the long run. Rethinking the values would allow the development of further new forms of tourism, which would attract a wider range of tourists to the settlement.
\end{abstract}

Keywords: tourism, tourist offer, SWOT analysis, natural and man-made values

\section{INTRODUCTION}

The intensification of globalization, the appreciation of environmental paradigms, and the changes in agriculture are shedding new light on the opportunities and chances of the countryside. The emergence of rural tourism can provide a solution to the challenges of the rural economy and society. Rural tourism can be interpreted as an opportunity to diversify the rural economy (KovÁCS, 2002). The tourism offers measurable positives for rural development. Tourism can be a tool for exploring local resources and thereby has a dynamic effect on the rural economy, as tourism can utilize resources that would result in more modest economic benefits or fall into deprivation, such as national parks and nature reserves. In this way, the intact natural environment and the surviving traditions of the regions can be explored as an attraction that can be interpreted as a developmental energy. Therefore, tourism becomes an important factor in regional and settlement development (LENGYEL, 1997; FATOSZ, 2007).

Natural and environmental factors alone are not an attraction in a specified area, as they are not able to endorse their function, so they are only present as a potential advantage and a possible opportunity. In order to natural and environmental factors become a resource, it is absolutely necessary to have certain basic infrastructure (KIS AND TÓTH, 2016). Elements of the tourism potential have an impact on the local economic and social life, as well as suitable for strengthening the development and competitiveness of the region by closely linking tourism and regional development. The tourism sector has a significant multiplier effect on other activities and sectors (Michalkó, 2005; FATOSZ, 2007).

Demand and supply are the two subsystems of tourism, or in other words, the main components of the market. The relationship between supply and demand is created by marketing and the flow and stay of tourists (LENGYEL, 1997). There are three basic conditions OF touristic demand: motivation, disposable income, and leisure time. We speak about realized tourism demand if all the three conditions meet. The system of tourism is 
changing dynamically and as an open system interacts with the natural, political, economic technological and social environment, all of which have an impact on the forming of demand (NAGY, 2007; KALMÁRNÉ, 2018). The touristic offer means the total of the tourism services and attractions of the destinations, such as accommodation, hospitality and programs for tourists (VÁSÁRHELYI, 2009). The touristic offer includes elements that are important for tourists during their trips. The elements of supply are the destination receptivity, the attitude of the local population and managers towards tourism, as well as the organization of civil society and local entrepreneurs. The basic infrastructure elements, such as accessibility routes, are also included (VÁSÁRHELYI, 2009; KALMÁRNÉ, 2018).

Tourism can be considered an economic, social and natural phenomenon at the same time. There is a correlation between tourism and its environment, the development of tourism is influenced by certain factors of the environment, and tourism has an impact on its environment. The interaction can be both positive and negative (PALANCSA, 2005). The most important component of the tourism's economic impact is on spending money on tourism, for example, on hotels, restaurants, and means of transport, museums and shops, which spills over into the economy and other sectors as well. It creates jobs, income and attracts capital investments to the specified area, so it has a multiplier effect (LENGYEL, 1997; PALANCSA, 2005). On the other hand, tourism has a significant impact on the economic environment through the development of tourism, as it involves the development of infrastructure, the construction and operation of restaurants and hotels (LENGYEL, 1997). The socio-cultural effects of tourism on tourism destinations mean changes in the daily quality of life of the population, while the transformation of values, norms and identities can be interpreted as a cultural effect (GLASSON ET AL., 1995 QUOTED IN XIAOPING AND YONG, 2019). In this case, tourism is the cause of the environmental and cultural damage, or the initiator of the positive changes (RÉGI, 2017).

\section{MATERIALS AND METHODS}

As part of the primary research, a questionnaire interview was conducted with owners of restaurants and accommodations in Ópusztaszer. We conducted a structured in-depth interview with the marketing director of the Ópusztaszer National Historical Memorial Park, the owner of the Csillagösvény Labyrinth, a member of the Cseppentö family and the head of the local Tourinform Office about the basic data on service providers and the demand and supply of Ópusztaszer tourism. In addition to the questionnaires, we also had informal conversations with the managers of the hoteliers and restaurants, and during the personal meetings we also had the opportunity to visit the field. Nine accommodations and two restaurants were involved in the research. However, the opinions of nine persons were relevant, because two accommodations had one owner and the owner of Szeri Csárda and Szeri Kemping was also one person. We used literature and internet sources as well to prepare the study.

Ópusztaszer is located in Csongrád-Csanád County, in the neighborhood of Baks, Kistelek and Dóc in the Kistelek district. In Ópusztaszer, agriculture and tourism provide a livelihood for the people living here. The population of Ópusztaszer has been steadily declining since 2010 (TEIR, 2020). According to the 105/2015. (IV. 23.) Regulation of the Government, the settlement is considered to be beneficiary from a social, economic and infrastructural point of view. There are three large tourist service providers in Ópusztaszer. As a result, restaurants and accommodations operate in the settlement throughout the whole year, thus creating the tourist infrastructure which is suitable for receiving tourists. The largest tourist service provider in Ópusztaszer is the Ópusztaszer National Historical Memorial Park, which is one of our most significant historical monuments. Its history 
Review on Agriculture and Rural Development 2020 vol. 9 (1-2) ISSN 2677-0792

DOI: 10.14232/rard.2020.1-2.3-8

dates back to the 1880s. The Memorial Park was completed in 1995, which was dreamed up by Ferenc Erdei in 1970 (SZABÓ, 2005). The Memorial Park seeks to familiarize our past, traditions and history with the visitors via memorial sites, buildings and exhibitions. Its wide range of services and diverse events allows it to receive visitors all year round. The historical site of the Hungarian conquest inspired the Cseppentö family, who moved to Ópusztaszer in 1985 and started breeding horses here, with the historical horse breed, Akhal Teke, which at that time was the only such breed in Hungary. Today, the Cseppentö family primarily organizes equestrian programs and activities. The Csillagösvény Eco Adventure Park is located next to the Ópusztaszer National Historical Memorial Park, which is unique in Central Europe, because the labyrinth theme park is built from the nearby natural ingredients. On the other hand, the Csillagösvény Labyrinth is the largest hedge maze in Europe and it creates a really exciting atmosphere via Hungarian history, geography and wildlife [1].

There are nine accommodations and two restaurants in Ópusztaszer. The type of accommodation is guest house which also known as holiday house, apartment, as well as yurt accommodation, camping and youth hostel. Both types of restaurants are inns. The accommodation providers in the settlement can accommodate about $400-420$ people in total, while the inns can seat 580 people.

\section{RESULTS}

Ópusztaszer has many man-made and natural values, most of which are still present in the settlement as untapped opportunities. We made an inventory of the values of Ópusztaszer (Table 1), in which the websites of the interviewees and the tourism service providers also helped us.

Table 1: Man-made and nature values of Ópusztaszer

\begin{tabular}{|c|c|c|}
\hline \multicolumn{2}{|c|}{ Man-made values } & Natural values \\
\hline $\begin{array}{l}\text { Religious places } \\
\text { Kisboldogasszony Chapel } \\
\text { Magyarok Nagyasszonya } \\
\text { Church } \\
\text { Ecumenical Chapel } \\
\text { Ányási Pallavicini Chapel } \\
\text { Szeri Monastery } \\
\text { Historical places, } \\
\text { monuments } \\
\text { Ópusztaszer National } \\
\text { Historical Memorial Park } \\
\text { Pallavicini Palace } \\
\text { Csontospart Ópusztaszer } \\
\text { Monument to the Seven } \\
\text { Arrows of Hungarians } \\
\text { Hantházi Croft } \\
\text { Monuments } \\
\text { Csillagösvény Labyrinth } \\
\text { Cseppentő farm } \\
\text { Hiking Trail } \\
\text { Alföldi Kék Tour route }\end{array}$ & $\begin{array}{l}\text { Events organized by the } \\
\text { Historical National Park } \\
\text { Pünkösdölö, Szeri Easter, } \\
\text { Hungarian Christmas, Szobori } \\
\text { Farewell, National Assembly of } \\
\text { Hungarians, Melon Day, St. } \\
\text { Michael's Wine Filter, Harvest, } \\
\text { Craftsmen's Day, St. Stephen's } \\
\text { Day } \\
\text { Events and Festival organized by } \\
\text { the Cseppentö Family } \\
\text { Hello "Ugar" Music Festival, } \\
\text { Equestrian Camps and Tours, } \\
\text { Cattle Herding on Horseback } \\
\text { Events organized by the } \\
\text { Municipality } \\
\text { Village Day } \\
\text { Folk culture } \\
\text { Works of local craftsmen (basket } \\
\text { weaving, saddle making, felting) }\end{array}$ & $\begin{array}{l}\text { Flora and fauna } \\
\text { Bird and flora of } \\
\text { Ópusztaszer } \\
\text { (Pusztaszeri) forest } \\
\text { Akhal Teke Stud } \\
\text { Protected areas } \\
\text { The village and its } \\
\text { surroundings are part of } \\
\text { the Pusztaszer } \\
\text { Landscape Protection } \\
\text { Area } \\
\frac{\text { Water }}{\text { Tisza River and }} \\
\text { floodplain, thermal } \\
\text { water }\end{array}$ \\
\hline
\end{tabular}


Based on the natural and man-made values of Ópusztaszer, the forms of tourism were written in a table supported by examples (Table 2). Historic sites are the basis of cultural tourism, natural values and the hedge maze can be linked to ecotourism, cattle herding is part of agro-tourism, Akhal Teke stud and equestrian tours belong to equestrian tourism, while pilgrimage sites to religious tourism, types of accommodation and preservation of traditions and events are related to rural tourism.

Table 2: The specific appearance of the forms of rural tourism in Ópusztaszer

\begin{tabular}{|c|c|c|c|c|c|}
\hline \multicolumn{6}{|c|}{ Rural tourism } \\
\hline $\begin{array}{l}\text { Cultural } \\
\text { tourism }\end{array}$ & Ecotourism & Agro-tourism & Horse tourism & $\begin{array}{l}\text { Religious } \\
\text { tourism }\end{array}$ & $\begin{array}{l}\text { Village } \\
\text { tourism }\end{array}$ \\
\hline $\begin{array}{l}\text { Historic } \\
\text { sites: } \\
\text { Ópusztaszer } \\
\text { National } \\
\text { Historical } \\
\text { Memorial } \\
\text { Park }\end{array}$ & $\begin{array}{l}\text { The } \\
\text { services of } \\
\text { the } \\
\text { Cseppentö } \\
\text { family's } \\
\text { business: } \\
\text { horse riding } \\
\text { tours }\end{array}$ & $\begin{array}{l}\text { Cattle herding, } \\
\text { Akhal Teke } \\
\text { Stud }\end{array}$ & $\begin{array}{l}\text { The services of } \\
\text { the Cseppentö } \\
\text { family's } \\
\text { business: horse } \\
\text { riding tours } \\
\text { and } \\
\text { demonstrations }\end{array}$ & $\begin{array}{l}\text { Ecumenical } \\
\text { religious } \\
\text { routes, } \\
\text { Places of } \\
\text { pilgrimage: } \\
\text { Szeri } \\
\text { Monastery }\end{array}$ & $\begin{array}{l}\text { Cottages, } \\
\text { Local } \\
\text { artisans }\end{array}$ \\
\hline
\end{tabular}

In order to map the touristic situation of Ópusztaszer, we performed a SWOT analysis (Table 3), which helps to map the strengths and opportunities that result in the sustainability of Ópusztaszer tourism. We have drafted the weaknesses and threats that are the biggest risk factors for the future.

Strength: In Ópusztaszer, natural and man-made values have a prominent role among the strengths. The village also offers unique attractions in the world, such as the Feszty panorama, the Csillagösvény Labyrinth and the Akhal Teke stud. One of our most significant historical monuments is the Ópusztaszer National Historical Memorial Park, so the name Ópusztaszer is known throughout the country. On the impact of these famous sights, local accommodation and new restaurants opened that can admit a significant number of tourists. Building on the values of the settlement, several forms of tourism have developed, which offer an experience and attraction available to a wide range of tourists.

Weaknesses: Regarding the weaknesses, I would like to highlight the lack of cooperation among tourism service providers in the settlement. The local Tourist Destination Management organization does not perform its function, so it does not play a role in strengthening the collaboration either. Accessibility to Ópusztaszer is difficult due to the lack of transport infrastructure. The unfavorable location of the Tour inform Office only provides information on travel and attractions for guests who visit the Memorial Park.

Opportunities: The utilization of natural and man-made values should be rethought so that new forms of tourism could develop in the settlement, which could contribute to attracting a wider range of tourists. For example, the operation of the castle as a hostel could provide a basis for the development of conference and incentive tourism, the thermal water supply under the settlement would provide an opportunity to build a spa. New forms of tourism would attract a larger proportion of not only domestic but also foreign guests to the settlement. The cooperation among local service providers ensure an opportunity for joint marketing activities and the development of joint program packages, which would increase the number of nights spent in the settlement and the area. The active operation of the local Tourist Destination Management organization should be promoted, which would 
strengthen the cooperation among the tourism service providers and could also play an important role in the development of joint marketing activities.

Threats: The biggest threat is the municipality's lack of interest in local tourism. During the research we could not contact the local authorities, we did not find any information about the local tourism on the website of the settlement. The local tourism service providers also thought that the local government was not interested in cooperation, joint marketing or development.

Table 3: SWOT analysis of Ópusztaszer tourism

\begin{tabular}{|c|c|}
\hline Strength & Weaknesses \\
\hline $\begin{array}{l}\text { Natural features } \\
\text { Traditions and built heritage } \\
\text { Diverse events } \\
\text { Unique attractions } \\
\text { Familiarity and attendance } \\
\text { Existing and operating tourism businesses } \\
\text { Development of a significant number of } \\
\text { forms of tourism }\end{array}$ & $\begin{array}{l}\text { Weaknesses in transport infrastructure } \\
\text { The unfavorable location of the Tourinform } \\
\text { Office } \\
\text { Seasonality of tourism } \\
\text { Lack of cooperation among local tourism } \\
\text { providers } \\
\text { Demographic problems: declining } \\
\text { population, aging } \\
\text { Lack of joint marketing } \\
\text { Untapped human and natural values } \\
\text { Formal operation of a local Tourist } \\
\text { Destination Management organization } \\
\text { Lack of higher category accommodation } \\
\text { and restaurants }\end{array}$ \\
\hline Opportunities & Threats \\
\hline $\begin{array}{l}\text { Expanding the tourism product portfolio by } \\
\text { rethinking the use of natural and man-made } \\
\text { values } \\
\text { Strengthen cooperation between local } \\
\text { tourism providers } \\
\text { Development of joint program packages and } \\
\text { marketing activities in the settlement } \\
\text { Facilitate the active operation of the local } \\
\text { Tourist Destination Management } \\
\text { organization } \\
\text { Reception of foreign guests in the village }\end{array}$ & $\begin{array}{l}\text { Lack of interest of the local population and } \\
\text { local government } \\
\text { Economic crisis phenomena }\end{array}$ \\
\hline
\end{tabular}

\section{CONCLUSION}

The main aim of the study was to examine the touristic offer of Ópusztaszer, taking into account the man-made and natural values of the settlement, as well as the local tourism service providers. We made a SWOT analysis to map the tourist situation of the settlement, in which we summarized the strengths, weaknesses, opportunities and threats for the future. Many forms of tourism have developed in the settlement, including equestrian tourism, village tourism, cultural tourism and ecotourism. During the inventory of manmade and natural values, we found that the settlement has many untapped opportunities. By rethinking their use they could become later a strength of the settlement, contributing to sustainable tourism in the settlement. Rethinking the values of the settlement promotes the 
development of further forms of tourism which contributes to attracting a wider layer of tourists to the settlement.

\section{REFERENCES}

FAtosz: FAlusi ÉS Agroturizmus OrszÁgos SzÖvetsége (2007): Falusi turizmus tájékoztató. 14: (1-2).

KALMÁRNÉ, R. CS. (2018): Turisztikai motiváció és életstílus összefüggései a belföldi utazási szokásokban. Gödöllő. pp. 23-28.

KIS, K., TóтH, A. (2016): Az ökoturizmus helyi rendszerének vizsgálata Poroszlón, különös tekintettel a Tisza-tavi Ökocentrum helyi gazdaságfejlesztési szerepének értékelésére. Észak-magyarországi Stratégiai Füzetek 13:(1), pp. 73-91.

KovÁCS, D. (2002): Falusi turizmus az átalakuló mezőgazdaság és a vidék gazdaságának egyik diverzifikációs lehetősége Magyarországon. Gödöllő. pp. 5-7, 64

LENGYEL, M. (1997): A turizmus versenyképességét befolyásoló tényezők. Műhelytanulmány 16. kötet. Budapesti Közgazdaságtudományi Egyetem. Budapest. pp. 814.

MICHALKÓ, G. (2005): A Tisza-tó turisztikai potenciálja. Földrajzi Értesítő, 54:(1-2), 129147.

NAGY, A. (2007): A turizmus tendenciáinak vizsgálata Magyarországon. Gödöllő. p. 7.

PALANCSA, A. (2005): A turizmus hatása a gazdasági rendszerekre. pp. 536-551.

RÉGI, T. (2017): A turizmus és társadalmi változás kapcsolatának néhány antropológiai és szociológiai értelmezése. In: Régi T., Rácz T., Michalkó G. (szerk.): Turizmus és transzformáció. Kodolányi János Főiskola. Orosháza-Budapest. pp. 11-28.

SzABÓ, G., L. (2005): Jelölt hely. In: Tandi L.(szerk.): Legendák földjén fejezetek az Ópusztaszeri Nemzeti Történeti Emlékpark Krónikájából. Az Ópusztaszeri Nemzeti Történeti Emlékpark KHT. pp. 29-44.

TEIR: Országos Területfejlesztési és Területrendezési Információs Rendszer (2018): Lakónépesség. $\quad$ https://www.teir.hu/helyzet-ter-kep/kivalasztott-mutatok.html> (2019.05.10.)

VÁSÁRHELYI, T. (2009): A turizmus fejlesztése. Eger. p. 18.

XiAOPING, Z., YONG, Y., Jun, L. (2019): Sociocultural Impacts of Tourism on Residents of World Cultural Heritage Sites in China. Guangzhou.

[1]: http://csillagosveny.com/rolunk/bemutatkozo/ (2020.05.06.)

105/2015. (IV. 23.) Korm. rendelet a kedvezményezett települések besorolásáról és a besorolás feltételrendszeréröl 